\title{
REPRODUCTIVE COMPATIBILITY DESPITE LARGE-SCALE GENETIC DIVERGENCE IN CEPAEA NEMORALIS
}

\author{
MICHAEL S. JOHNSON*, O. COLIN STINE AND JAMES MURRAY \\ Department of Biology, University of Virginia, Charlottesville Va. 22901, USA \\ Received 26.iv.84
}

\section{SUMMARY}

Cepaea nemoralis is remarkable for its geographic variation for both shell polymorphism and allozymes. An electrophoretic study of 20 loci revealed genetic identities as low as 0.53 between English and Italian populations. Despite this genetic divergence, crosses among American, English, and Italian stocks demonstrate that populations of $C$. nemoralis are reproductively compatible on a continental scale.

This reproductive compatibility in the face of large-scale genetic divergence indicates the danger of using a genetic index to assess reproductive relationships. The decoupling of genetic divergence from speciation emphasizes the limitations of viewing the process of speciation solely in genetic terms. A comparison of Cepaea with another genus of land snails, Partula, suggests that competition may be an important determinant of the likelihood of speciation.

C. nemoralis from Lexington, Virginia, were included in the matings and electrophoretic comparisons, in order to test conflicting proposals on the origin of that population. Both sets of data favour a British, rather than an Italian, origin, but are also compatible with earlier evidence that the Lexington population is of hybrid origin.

\section{INTRODUCTION}

Great changes have recently taken place in our views about the genetic structure of species. It is now clear from the electrophoresis of proteins that there is a wealth of genetic variation within populations (e.g., Powell, 1975; Nevo, 1978). Other studies of natural populations have shown that under appropriate conditions genetic differentiation may proceed despite continuing gene flow (Bradshaw, 1960; Bush, 1969). Theoretical analysis supports the conclusion that species with continuous and widespread distributions are unlikely to be genetically homogenous, and may contain incipient parapatric species (Clarke, 1966; Maynard Smith, 1966; Dickinson and Antonovics, 1973; Endler, 1977).

Land snails, such as the polymorphic species Cepaea nemoralis, are particularly suitable for the study of genetic variation among populations (for reviews see Jones et al., 1977; Clarke et al., 1978). Differentiation between populations of $C$. nemoralis has been demonstrated at three separate levels. In some places, the frequencies of the genes controlling shell colour and banding depend upon the habitat in which the populations are living, largely because of selective predation on the snails (e.g., Cain and

\footnotetext{
* Permanent address: Department of Zoology, University of Western Australia. Nedlands, Western Australia 6009
} 
Sheppard, 1950, 1954). Not all populations, however, are differentiated on so small a scale. Areas with similar frequencies of partciular genes affecting the shell polymorphism may extend for 10 to $25 \mathrm{~km}^{2}$ and include a variety of habitats (Cain and Currey, 1963). A similar or larger scale of variation exists for genes controlling polymorphic enzymes (Johnson, 1976; Jones et al., 1980; Ochman et al., 1983). These "area effects" have been variously attributed to micro-climatic selection (Cain and Currey, 1963), to founder effects (Goodhart, 1963), or to local co-adaptations of the genotype (Goodhart, 1963; Clarke, 1968). Finally, there is differentiation on a larger geographical scale, such as the cline in the frequency of yellow shells which stretches across Europe (Jones et al., 1977).

The wide range, limited mobility, and great variation in Cepaea suggest that incipient reproductive isolation might be developing between distant populations. In other polymorphic land snails, for example, reproductive isolation can be well developed between sympatric taxa connected by chains of interbreeding populations only a few kilometers in length (Clarke and Murray, 1969; Murray and Clarke, 1980).

We report here the results of matings undertaken to find out whether isolation might be detected among geographically distant populations of C. nemoralis, whose genetic divergence was quantified by electrophoresis of twenty enzyme loci. The results indicate reproductive compatibility despite uniquely high levels of allozymic divergence among these conspecific populations.

This study was also designed to investigate a second question. $C$. nemoralis has been introduced to several localities in North America, the best-known introduction being that at Lexington, Virginia (Howe, 1898; McConnell, 1935; Brussard, 1975; Richards and Murray, 1975). There is some doubt about the source of the founders of this population. Howe (1898) believed that the material came from Italy, but he also noted a possible alternative source in Great Britain. Brussard (1975) argued that electrophoretic data for two polymorphic loci favour an Italian origin, since the Lexington population was allozymically different from three samples collected in Wales. There is evidence, however, of significant change in the Lexington populations since Howe's time, notably the disappearance of brown shells, a phenotype characteristic of northern Europe. A comparison of the patterns of reproductive compatibility and genetic similarity of Lexington snails with animals from Britain or Italy, might help to trace their origin. To these ends our crosses used American, English, and Italian snails.

\section{Materials ANd Methods}

The American stock was taken from the "Redwood" site (intersection of Interstate Highway 64 and US 11) in Lexington, Virginia. The English stock came from the sand dunes at Berrow in Somerset. The Italian stock was collected at Santa Croce near Pavia. An additional Italian sample from near Florence was used for the electrophoresis but not for matings.

All the animals used in the matings were collected as juveniles and maintained in isolation until maturity. Animals were given serial numbers as they matured and were assigned to matings by means of a table of random numbers. Twenty-four individuals from each source population were crossed 
as follows:

\author{
8 American $\times$ English \\ 8 English $\times$ Italian \\ 8 Italian $\times$ American \\ 4 American $\times$ American \\ 4 English $\times$ English \\ 4 Italian $\times$ Italian
}

Matings were established in the winter of 1977 and the spring of 1978 and were maintained until December 1979. The numbers of young from each mating were counted and six young from each productive mating were reared for a second generation. These young were mated as follows:

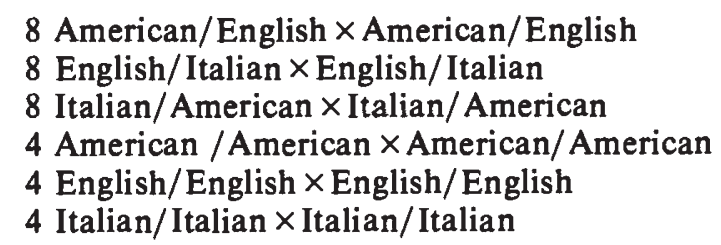

The second generation was crossed so as to avoid inbreeding and to equalise as much as possible the contributions of offspring from the original matings. They were established in the spring of 1979 and maintained until January 1980. The numbers of offspring were recorded. Animals dying during the course of the experiments were replaced from virgin stocks.

All mated pairs were maintained on sandy loam in $20 \mathrm{~cm}$ flower pots, each covered with a sheet of glass. They were fed oatmeal and lettuce, and were provided with lumps of natural chalk. The snails oviposited in the soil and eggs were allowed to hatch in the pots. Emerging young were counted and preserved, except for the individuals chosen for rearing. These were transferred to $10 \times 10 \times 2 \mathrm{~cm}$ plastic boxes. Moistened toilet paper in the bottom of the boxes maintained a humid atmosphere, and the young snails were fed a diet of oatmeal, lettuce, and powdered natural chalk.

Samples from these matings and from the Florence population were examined by conventional starch-gel electrophoresis for variation in 15 enzymes, representing 20 gene loci. The enzymes examined and the electrophoretic buffers used are shown in table 1.

Allelic designations indicate relative electrophoretic mobilities of the corresponding allozymes, and wherever possible correspond with those used by Jones et al., (1980). The inheritance of allozymes for several of these loci has been confirmed previously (Brussard and McCracken, 1974; Johnson, 1979). Examination of $F_{1}$ and $F_{2}$ offspring from the interpopulational crosses confirmed the inheritance of allozyme differences between the populations.

Based on the 20 loci, unbiased estimates of genetic identity, I, and genetic distances (Nei, 1978) were calculated for all pairs of the four populations.

\title{
3. RESUlts
}

(i) Matings

The results of the 72 matings among the three different stocks are shown in tables 2 and 3 . It is quite clear that there is nothing like complete 
TAble 1

Enzymes assayed and buffer systems used in the study of genetic variation in Cepaea nemoralis

\begin{tabular}{|c|c|c|c|c|}
\hline Enzyme & Locus & Tissue* & $\begin{array}{l}\text { Quaternary } \\
\text { structure }\end{array}$ & $\begin{array}{l}\text { Electrophoretic } \\
\text { buffer } \ddagger\end{array}$ \\
\hline Esterase & Est-1 & $\mathbf{F}$ & monomer & TEB \\
\hline Glucose-6-phosphate dehydrogenase & G6pd & $\mathrm{F}$ & multimer & TEB \\
\hline \multirow[t]{2}{*}{ Glutamate-oxaloacetate transaminase } & Got-1 & $\mathbf{H}$ & no data & TM \\
\hline & Got-2 & $\mathbf{H}$ & no data & TM \\
\hline Indophenol oxidase & Ipo-2 & $\mathbf{F}$ & dimer & TEB \\
\hline \multirow[t]{2}{*}{ Isocitrate dehydrogenase } & Idh-1 & $\mathbf{H}$ & dimer & TM \\
\hline & $I d h-2$ & $\mathbf{H}$ & no data & TM \\
\hline Lactate dehydrogenase & $L d h$ & $\mathbf{F}$ & no data & TEB \\
\hline \multirow[t]{2}{*}{ Leucine aminopeptidase } & Lap-1 & $\mathbf{H}$ & monomer & TEB \\
\hline & Lap-2 & $\mathbf{H}$ & monomer & TEB \\
\hline Leucylproline peptidase & $L p p$ & $\mathbf{H}$ & dimer & $\mathrm{LiOH}$ \\
\hline Leucyltyrosine peptidase & Ltp & $\mathbf{H}$ & monomer & $\mathrm{LiOH}$ \\
\hline \multirow[t]{2}{*}{ Malate dehydrogenase } & $M d h-1$ & $\mathbf{H}$ & dimer & TC \\
\hline & $M d h-2$ & $\mathbf{H}$ & no data & TC \\
\hline Mannosephosphate isomerase & $M p i$ & $\mathbf{H}$ & monomer & TC \\
\hline Nucloside phosphorylase & $N p$ & $\mathbf{F}$ & trimer & TEB \\
\hline 6-Phosphogluconate dehydrogenase & $6 P g d$ & $\mathbf{H}$ & dimer & $\mathrm{TC}$ \\
\hline Phosphoglucose isomerase & $P g i$ & $\mathbf{H}$ & dimer & TC \\
\hline \multirow[t]{2}{*}{ Phosphoglucomutase } & Pgm-2 & $\mathbf{H}$ & monomer & TM \\
\hline & Pgm-3 & $\mathbf{H}$ & monomer & TM \\
\hline
\end{tabular}

* $\mathrm{F}=$ foot $\mathbf{H}=$ hepatopancreas.

+ Based on isozyme patterns of heterozygotes.

$\ddagger$ TEB $=$ buffer $6, \mathrm{TM}=$ buffer $9, \mathrm{TC}=$ buffer $4, \mathrm{LiOH}=$ buffer 2 of Selander et al. (1971).

TABle 2

Matings among stocks of Cepaea nemoralis from America, England, and Italy, giving means and standard errors of numbers of offspring per attempted mating and per mating that produced at least some offspring

\begin{tabular}{|c|c|c|c|c|c|c|}
\hline \multirow[b]{2}{*}{ Type } & \multirow{2}{*}{$\begin{array}{l}\text { No. of } \\
\text { matings }\end{array}$} & \multicolumn{2}{|c|}{ Nos. of offspring } & \multirow{2}{*}{$\begin{array}{l}\text { No. of } \\
\text { successful } \\
\text { matings }\end{array}$} & \multicolumn{2}{|c|}{ Nos. of offspring } \\
\hline & & $x$ & S.E. & & $x$ & S.E. \\
\hline American/English & 8 & $209 \cdot 25$ & 52.67 & 7 & $239 \cdot 14$ & $50 \cdot 08$ \\
\hline English/Italian & 8 & $81 \cdot 00$ & 27.87 & 6 & $108 \cdot 00$ & $29 \cdot 44$ \\
\hline Italian/American & 8 & $171 \cdot 00$ & 31.88 & 8 & $171 \cdot 00$ & $31 \cdot 88$ \\
\hline American/American & 4 & $167 \cdot 00$ & $24 \cdot 51$ & 4 & $167 \cdot 00$ & $24 \cdot 51$ \\
\hline English/English & 4 & $215 \cdot 00$ & $84 \cdot 00$ & 3 & $286 \cdot 67$ & 61.95 \\
\hline Italian/Italian & 4 & 213.00 & $60 \cdot 07$ & 4 & $213 \cdot 00$ & $60 \cdot 07$ \\
\hline
\end{tabular}

reproductive isolation between any of the populations. Only four of the 36 matings of the first generation failed to produce any offspring at all, and they are scattered over three groups, two experimental and one control. The second generation was rather less successful than the first for experimentals and controls. However, at least some of each class of hybrid crosses produced young, and the numbers of young per mating exceeded those from the controls. These results imply that populations of $C$. nemoralis maintain genetic compatibility on a scale of many hundreds of kilometres. 
TABLE 3

Matings among the offspring of the matings recorded in table 2, giving means and standard errors of numbers of offspring per attempted mating and per mating that produced at least some offspring

\begin{tabular}{|c|c|c|c|c|c|c|}
\hline \multirow[b]{2}{*}{ Type } & \multirow{2}{*}{$\begin{array}{l}\text { No. of } \\
\text { matings }\end{array}$} & \multicolumn{2}{|c|}{ Nos. of offspring } & \multirow{2}{*}{$\begin{array}{l}\text { No. of } \\
\text { successful } \\
\text { matings }\end{array}$} & \multicolumn{2}{|c|}{ Nos. of offspring } \\
\hline & & $x$ & S.E. & & $x$ & S.E. \\
\hline $\mathrm{F}_{2}$ American/English & 8 & $77 \cdot 88$ & $35 \cdot 89$ & 5 & $124 \cdot 60$ & $46 \cdot 38$ \\
\hline$F_{2}$ English/Italian & 8 & $18 \cdot 13$ & $14 \cdot 33$ & 2 & $72 \cdot 50$ & $42 \cdot 50$ \\
\hline $\mathrm{F}_{2}$ Italian/American & 8 & $41 \cdot 13$ & 30.46 & 3 & $109 \cdot 67$ & 69.99 \\
\hline $\mathrm{F}_{2}$ American/American & 4 & 0 & 0 & 0 & 0 & 0 \\
\hline $\mathrm{F}_{2}$ English/English & 4 & $88 \cdot 00$ & $45 \cdot 11$ & 3 & $117 \cdot 33$ & $48 \cdot 46$ \\
\hline $\mathrm{F}_{2}$ Italian/Italian & 4 & $10 \cdot 50$ & $10 \cdot 50$ & 1 & $42 \cdot 00$ & - \\
\hline
\end{tabular}

There is a great deal of variation within each group of matings; even when matings that have produced no offspring are excluded, the numbers of offspring per mating show two- to eightfold differences within each group. As the standard errors averaged 22 per cent of their respective means, it is difficult to assess the real extent of differences between the groups. For example, analysis of variance using all the six types of matings as treatments failed to detect any significant heterogeneity among the matings $\left(\mathrm{F}_{5,30}=1 \cdot 40\right.$; or, excluding unproductive matings, $F_{5,26}=1 \cdot 84$ ). Comparison of each group of experimental crosses with the corresponding "parental" groups of controls showed significantly fewer offspring only for the English $\times$ Italian matings $\left(t_{14}=2.40 ; P<0.05\right)$. This difference did not extend to the second generation, however.

\section{(ii) Electrophoresis}

Variation was found at 16 of the 20 loci examined (table 4). Within populations, polymorphism was detected at 30 to 50 per cent of the loci, while individual heterozygosity averaged 11.6 per cent. In addition to this extensive variation within populations, there is considerable divergence among the populations. The average genetic identity among the four populations is only 0.65 , with a range of 0.53 to 0.83 (table 5). These low genetic identities result from the fixation or near-fixation of alternative alleles in different populations (table 4; fig. 1).

The most similar of the populations are Berrow and Lexington, which show large genetic divergence from the Santa Croce population. The snails from Florence are genetically intermediate among the others, rather than being particularly similar to those from Santa Croce.

\section{Discussion}

\section{(i) Genetic divergence and speciation}

The matings clearly demonstrate a high degree of genetic compatibility between distant populations: any postmating isolation, such as that which might exist between English and Italian snails, is weak. These results are compatible with the apparent absence of barriers to interbreeding in the laboratory between English and Pyrenean snails (Cook, 1967; Cain et al., 
TABLE 4

Allelic frequencies at 16 loci in 4 populations of Cepaea nemoralis. Calculations of average heterozygosity include an additional 4 monomorphic loci. Sample sizes in parentheses

\begin{tabular}{|c|c|c|c|c|c|}
\hline Locus & Allele & $\begin{array}{l}\text { Berrow, } \\
\text { England } \\
\text { (11) }\end{array}$ & $\begin{array}{l}\text { Lexington, } \\
\text { Virginia } \\
(10)\end{array}$ & $\begin{array}{c}\text { Santa Croce, } \\
\text { Italy } \\
\text { (13) }\end{array}$ & $\begin{array}{c}\text { Florence, } \\
\text { Italy } \\
(10)\end{array}$ \\
\hline \multirow[t]{2}{*}{ Est-1 } & 100 & 0.15 & 0.11 & 0.88 & 1.00 \\
\hline & 97 & 0.85 & 0.89 & 0.12 & - \\
\hline \multirow[t]{3}{*}{ G6pd } & 103 & - & 0.07 & - & $0 \cdot 10$ \\
\hline & 100 & 1.00 & 0.93 & 0.96 & 0.90 \\
\hline & 97 & - & - & 0.04 & - \\
\hline \multirow[t]{2}{*}{ Ipo-2 } & 130 & - & $1 \cdot 00$ & 0.96 & 0.85 \\
\hline & 100 & 1.00 & - & 0.04 & 0.15 \\
\hline \multirow[t]{2}{*}{ Idh-1 } & 100 & 1.00 & 1.00 & 0.73 & 1.00 \\
\hline & 92 & - & - & 0.27 & - \\
\hline \multirow[t]{2}{*}{$I d h-2$} & 100 & 0.80 & 0.25 & 0.81 & 0.85 \\
\hline & 78 & 0.20 & 0.75 & 0.19 & 0.15 \\
\hline \multirow[t]{2}{*}{ Lap-1 } & 100 & 1.00 & $1 \cdot 00$ & 1.00 & - \\
\hline & 90 & - & - & - & 1.00 \\
\hline \multirow[t]{5}{*}{ Lap-2 } & 125 & - & - & 0.96 & - \\
\hline & 120 & - & - & 0.04 & - \\
\hline & 105 & - & 0.30 & - & 0.70 \\
\hline & 95 & 1.00 & - & - & 0.30 \\
\hline & 90 & - & 0.70 & - & - \\
\hline \multirow{3}{*}{$L_{p p}$} & 100 & 1.00 & 0.20 & 1.00 & - \\
\hline & 97 & - & - & - & 1.00 \\
\hline & 88 & - & 0.80 & - & - \\
\hline \multirow[t]{3}{*}{$L t p$} & 116 & - & - & 0.69 & - \\
\hline & 100 & 1.00 & 0.70 & 0.31 & 0.95 \\
\hline & 96 & - & 0.30 & - & 0.05 \\
\hline \multirow{3}{*}{$M d h-1$} & 100 & 0.50 & 1.00 & - & - \\
\hline & 90 & - & - & 1.00 & 1.00 \\
\hline & 60 & 0.50 & - & - & - \\
\hline \multirow[t]{2}{*}{$M p i$} & 115 & - & 0.05 & 1.00 & - \\
\hline & 100 & 1.00 & 0.95 & - & 1.00 \\
\hline \multirow{2}{*}{$N p$} & 110 & 0.11 & - & 0.54 & 0.25 \\
\hline & 100 & 0.89 & $1 \cdot 00$ & 0.46 & 0.75 \\
\hline \multirow[t]{3}{*}{$6 P g d$} & 125 & - & - & 1.00 & - \\
\hline & 115 & - & - & - & 1.00 \\
\hline & 100 & 1.00 & 1.00 & - & - \\
\hline \multirow[t]{2}{*}{$P g i$} & 100 & 0.05 & 0.05 & 1.00 & 0.55 \\
\hline & 50 & 0.95 & 0.95 & - & 0.45 \\
\hline \multirow[t]{2}{*}{$P g m-2$} & 150 & 0.23 & 0.11 & 0.08 & - \\
\hline & 100 & 0.77 & 0.89 & 0.92 & 1.00 \\
\hline \multirow[t]{2}{*}{$P g m \cdot 3$} & 200 & $0 \cdot 10$ & $0 \cdot 10$ & 0.88 & 0.50 \\
\hline & 100 & 0.90 & 0.90 & 0.12 & 0.50 \\
\hline \multicolumn{6}{|l|}{ Average } \\
\hline \multicolumn{2}{|l|}{$\begin{array}{l}\text { Heterozygosity } \\
(20 \text { loci) }\end{array}$} & 0.095 & 0.118 & $0 \cdot 121$ & 0.129 \\
\hline
\end{tabular}

1968), and support the current taxonomic treatment of $C$. nemoralis as a single speciess:

This genetic compatibility prevails despite a degree of genetic divergence which is unprecedented within a species. For perspective, approximately 80 per cent of electrophoretic comparisons between conspecific populations from a wide range of plants and animals have revealed genetic identities 
TABLE 5

Average genetic identities (above diagonal) and genetic distances (below diagonal) between populations of Cepaea nemoralis, based on 20 loci

\begin{tabular}{lcccc}
\hline & $\begin{array}{c}\text { Berrow, } \\
\text { England }\end{array}$ & $\begin{array}{c}\text { Lexington, } \\
\text { Virginia }\end{array}$ & $\begin{array}{c}\text { Santa Croce, } \\
\text { Italy }\end{array}$ & $\begin{array}{c}\text { Florence, } \\
\text { Italy }\end{array}$ \\
\hline Berrow & & 0.829 & 0.532 & 0.655 \\
Lexington & 0.188 & & 0.532 & 0.665 \\
Santa Croce & 0.631 & 0.631 & & 0.676 \\
Florence & 0.423 & 0.409 & 0.391 & \\
\hline
\end{tabular}

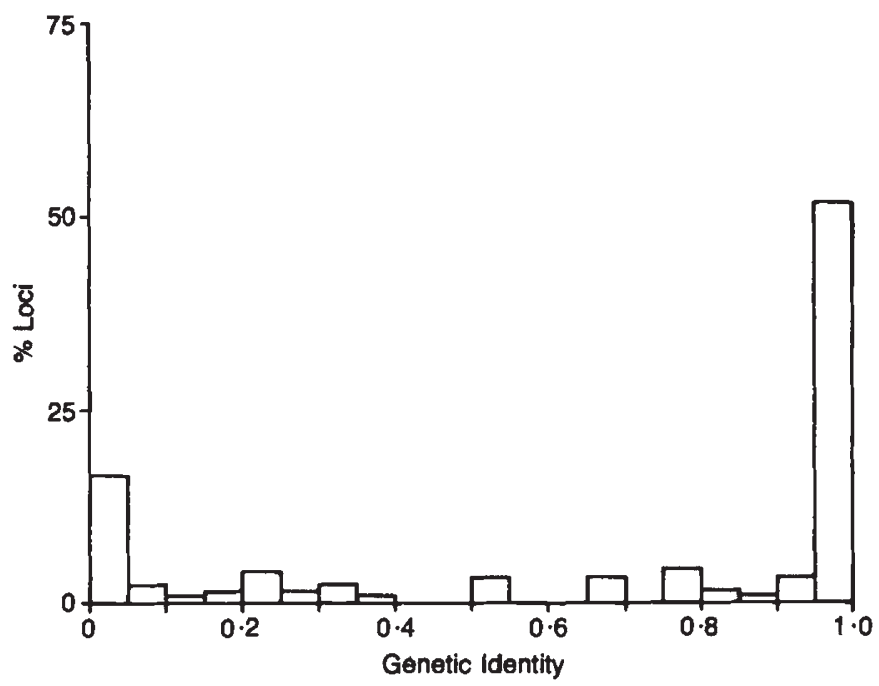

FIG. 1. Frequency distribution of loci with respect to genetic identity in comparisons among four populations of Cepaea nemoralis.

greater than 0.95 ; fewer than 2 per cent of such comparisons have values of $I$ lower than 0.85 (Thorpe, 1982). Thus, even the $I$ of 0.83 between populations of $C$. nemoralis from Berrow and Lexington is unusually low. The identities of less than 0.55 between these populations and that from Santa Croce are well below the modal value (approximately 0.75 ) for comparisons among congeneric species (Thorpe, 1982). Indeed, the genetic distances among the populations of $C$. nemoralis overlap the estimates obtained between humans and chimpanzees (King and Wilson, 1975; Bruce and Ayala, 1979).

This large allozymic divergence within a species emphasizes the possible hazards involved in using genetic similarities to infer reproductive relationships. For example, Thorpe (1982: p. 151) proposed that, "If allopatric populations of dubious status have genetic identities below about 0.85 it is improbable that they should be considered conspecific, while nominate species with $I$ values above about 0.85 should be considered doubtful if there is no other evidence of their specific status". Although this criterion was derived empirically, exceptions are sufficiently common to require caution. For example, reproductive isolation with little allozymic divergence has been found in birds (Avise and Aquadro, 1982), gophers (Patton et al., 
1972), fish (Avise et al., 1975; Kornfield et al., 1979), snails (Johnson et al., 1977, ms), Drosophila (Sene and Carson, 1977), and plants (Gottlieb, 1973; Crawford and Smith, 1982), indicating that great genetic similarity does not always indicate conspecific status. The data for $C$. nemoralis demonstrate that the genetic measure is also fallible at the other end of the scale; even conspecific populations may show very low genetic identities. Thus. taxonomic decisions based entirely on the degree of genetic similarity are subject to gross error, and allozymes must be treated with the same care as any other type of data.

In addition to their taxonomic implications, the low genetic identities within $C$. nemoralis raise the question of what determines whether speciation will occur. The genetic structure of $C$. nemoralis would appear to be intrinsically favourable for allopatric speciation. Variation within populations is great, and variation among populations is unusually large. In addition to the continental scale of divergence shown in this study, strong genetic subdivision occurs even within small regions (Johnson, 1976, 1979; Jones et al., 1980; Ochman et al., 1983). Furthermore, "area effects" for allozymes often are concordant among loci (Johnson, 1976; Ochman et al., 1983), perhaps suggesting incipient speciation. Although area effects have been cited as the early stages of an important mode of speciation (e.g., White, 1978) the genetic compatibility among populations of $C$. nemoralis emphasizes the difficulty of equating geographic patterns of differentiation with incipient speciation.

If speciation is not closely coupled to the amounts and patterns of genetic divergence, it follows tht it must be considered as a process in its own right, and not simply an incidental of overall genetic change (Cracraft, 1982). Since populations of $C$. nemoralis have not become reproductively isolated, despite an apparently favourable genetic subdivision, it is likely that speciation in Cepaea is under the control of extrinsic factors. A comparison with patterns of speciation in another genus of land snails, Partula, is suggestive in this regard. Like C. nemoralis, species of Partula are outcrossing hermaphrodites with low vagility and high heterozygosity. Species of Partula on the island of Moorea, however, have very high genetic identities suggesting that reproductive isolation has developed through relatively simple genetic changes (Johnson et al., 1977, ms). In common with other groups that have radiated on oceanic islands, Partula on Moorea has evolved in a depauperate fauna. In contrast, Cepaea belongs to the highly diverse European snail fauna, suggesting that competition and the availability of ecological niches could be important factors determining the amount and rate of speciation. Although the possible importance of competition for speciation has been recognized (e.g., Hutchinson, 1968; Rosenzweig, 1978; Littlejohn, 1981), most recent discussions of the diversity of modes of speciation have emphasised the patterns of genetic change (Bush, 1975; White, 1978; Templeton, 1981). Since genetic variation and subdivision are poor predictors of speciation, however, it may be worthwhile to give greater emphasis to the ecological perspective in searching for controls of speciation.

\section{(ii) Origin of the Lexington colony}

The American $C$. nemoralis were included in our comparisons in order to investigate the origin of the Lexington colony. Although reproductive compatibility between populations was generally high, the directions of 
differences in the crosses were consistent for both the $F_{1}$ and $F_{2}$. The mean number of offspring per mating can be ranked as:

$$
\text { American } \times \text { English }>\text { America } \times \text { Italian }>\text { English } \times \text { Italian. }
$$

This suggests that the American (Lexington) population might be more compatible with the English (Berrow) than with the Italian (Santa Croce) population. The electrophoretic data are consistent with this pattern, as the Lexington population shows greater similarity to Berrow than to either of the Italian populations. Thus, the quantitative evidence marginally favours an English, rather than Italian, origin of the Lexington population.

It is also essential, however, to consider the qualitative evidence, that is, the sharing of particular alleles. Brussard's (1975) view that the Lexington population came from Italy was based on the absence of brown shells (commonly found only in northern populations of $C$. nemoralis) and on differences between Lexington and Welsh populations in allelic composition at the Lap- 2 locus. The absence of an allele from a derived population is not very informative, because the allele might have been lost after colonisation. Indeed, the brown-shelled morph formerly occurred in the Lexington population (Howe, 1898) strengthening the suggestion of an English origin.

On the other hand, the presence of the Lap- $2^{105}$ and Lap $-2^{90}$ alleles ( $=$ Lap $-2^{a}$ and Lap $-2^{c}$ of Brussard, 1975) at Lexington and their absence from the Welsh populations argue against a Welsh origin. However, both alleles have been found in other British populations (Johnson, 1979), and the allele was not found in either of the Italian populations examined in the present study. Thus, Brussard's (1975) data are compatible with an English origin of the Lexington population.

In the present study, two additional alleles, $M d h-1^{100}$ and $6 P g d^{100}$ were found in Lexington and Berrow, but not in the Italian populations, again favouring a northern origin. Conflicting evidence, however, is provided by the $L t p^{96}$ allele, which was detected only at Lexington and Florence. Furthermore, the $L p p^{88}$ allele, which is common at Lexington, was not found in any of the other populations, leaving us without any evidence about its source.

The difficulty of establishing the origin of the Lexington population stems from the fact that fixation or near-fixation of alternative alleles may occur over a few km (Johnson, 1976; Jones et al., 1980; Ochman et al., 1983). Although there may be concordance among loci in a particular area, there need not be on a larger scale (Johnson, 1979). Thus, unless a comprehensive survey of geographic variation reveals alleles distinctly characteristic of particular regions, the origin of the Lexington population will remain obscure. Finally, the conflicting electrophoretic evidence and the intermediate performance of the American $\times$ Italian matings raise the possibility that both of Howe's (1898) theories of introduction might be correct, and that the Lexington population owes its origin, and its extensive variability, to hybridisation between stocks introduced from both Italy and Great Britain.

Acknowledgements. We are very grateful to Professor Bryan Clarke for the Berrow collection and to Professor C. F. Sacchi and Drs S. D. Jayakar, C. Violani and S. Malcevski for that from Santa Croce. Professor Clarke also provided helpful comments, including the suggestion of the possible importance of competition. We also thank Dr J. S. Jones and Messrs C. M. Austin and W. J. Barendse for comments on the draft. Funds were provided by the Department of Biology, University of Virginia, and the Australian Research Grants Scheme. 


\section{REFERENCES}

AVISE, J. C. AND AQUADRO, C. F. 1982. A comparative summary of genetic distances in the vertebrates: patterns and correlations. Evol. Biol., 15, 151-185.

AVISE, J. C., SMITH, J. J. AND AYALA, F. J. 1975. Adaptive differentiation with little genic change between two native California minnows. Evolution, 29, 411-426.

BRADSHAW, A. D. 1960. Population differentiation in Agrostis tenuis Sibth. III. Populations in varied environments. New Phytol., 59, 92-103.

BRUCE, E. J. AND AYAlA, F. J. 1979. Phylogetic relationships between man and the apes: electrophoretic evidence. Evolution, 33, 1040-1056.

BRUSSARD, P. F. 1975. Geographic variation in North American colonies of Cepaea nemoralis. Evolution, 29, 402-410.

BRUSSARD, P. F. AND McCRACKEN, G. F. 1974. Allozymic variation in a North American colony of Cepea nemoralis. Heredity, 33, 98-101.

BUSH, G. L. 1969. Sympatric host race formation and speciation in frugivorous flies of the genus Rhagoletis (Diptera, Tephritidae). Evolution, 23, 237-251.

BuSH, G. L. 1975. Modes of animal speciation. Ann. Rev. Ecol. Syst., 6, 339-364.

CAIN, A. J. AND Cur Rey, J. D. 1963. Area effects in Cepaea. Phil. Trans. Roy. Soc., B, 246, 1-181.

CAIN, A. J. AND SHEPPARD, P. M. 1950. Selection in the polymorphic land snail Cepaea nemoralis. Heredity, 4, 275-294.

CAIN, A. J. AND SHEPPARD, P. M. 1954. Natural selection in Cepaea. Genetics, 39, 89-116.

CAIN, A. J., SHEPPARD, P. M. AND KING, J. M. B. 1968. The genetics of some morphs and varieties of Cepaea nemoralis (L.) Phil. Trans. Roy. Soc. B, 253, 383-396.

CLARKE, B. C. 1966. The evolution of morph-ratio clines. Am. Natur., 100, 389-402.

CLARKE, B. C. 1968. Balanced polymorphism and regional differentiation in land snails. In Drake, E. T. (ed.) Evolution and Environment, Yale University Press, New Haven, Conn., pp. 351-368.

CLARKE, B., ARTHUR, W., HORSLEY, D. T. AND PARKIN, D. T. 1978. Genetic variation and natural selection in pulmonate molluscs. In V. Fretter and J. Peake (eds.) Pulmonates, Vol. 2A, Academic Press, London, pp. 219-270.

CLARKE, B. AND MURRAY, J. 1969. Ecological genetics and speciation in land snails of the genus Partula. Biol. J. Linn. Soc. London, 1, 31-42.

COOK, L. M. 1967. The genetics of Cepaea nemoralis. Heredity, 22, 397-410.

CRACRAFT, J. 1982. A nonequilibrium theory for the rate-control of speciation and extinction and the origin of macroevolutionary patterns. Syst. Zool. 31, 348-365.

CRAWFORD, D. J. AND SMITH, E. B. 1982. Allozyme variation in Coreopsis nuecensoides and C. nuecensis (Compositae), a progenitor-derivative species pair. Evolution, 36, 379-386.

DICKINSON, H. AND ANTONOVICS, J. 1973. Theoretical considerations of sympatric divergence. Am. Natur., 107, 256-274.

ENDler, J. 1977. Geographic Variation, Speciation, and Clines. Princeton Univ. Press.

GOODHART, C. B. 1963. "Area effects" and non-adaptive variation between populations of Cepaea (Mollusca). Heredity, 18, 459-465.

GotTlieb, L. D. 1973. Enzymatic differentiation and phylogeny in Clarkia franciscana, $C$. rubicunda, and C. amoena. Evolution, 27, 205-214.

HOWE, J. L. 1898. Variation in the shell of Helix nemoralis in the Lexington, Va., colony. Am. Natur., 32, 913-923.

HUTChinson, G. E. 1968. When are species necessary? In R. C. Lewontin (ed.) Population Biology and Evolution, Syracuse Univ. Press, pp. 177-186.

JOHNSON, M. S. 1976. Allozymes and area effects in Cepaea nemoralis from the western Berkshire Downs. Heredity, 36, 105-121.

JOHNSON, M. S. 1979. Inheritance and geographic variation of allozymes in Cepaea nemoralis. Heredity, 43, 137-141.

JOHNSON, M. S., CLARKE, B. AND MURRAY, J. 1977. Genetic variation and reproductive isolation in Partula. Evolution, 31, 116-126.

JOHNSON, M. S., MURRAY, J. AND CLARKE, B. MS. Allozymic similarities among species of in Partula on Moorea. Evolution, submitted.

JONES, J. S., LEITH, B. H. AND RAWLINGS, P. 1977. Polymorphism in Cepaea: a problem with too many solutions? Ann. Rev. Ecol. Syst. 109-143.

JONES, J. S., SELANDER, R. K. AND SCHNell, G. S. 1980. Patterns of morphological and molecular polymorphism in the land snail Cepaea nemoralis. Biol. J. Linn. Soc. London, 14, 359-387. 
KING, M. C. AND WILSON, A. C. 1975. Evolution at two levels: molecular similarities and biolgoical differences between humans and chimpanzees. Science, 188, 107-116.

KORNFIELD, I. L., RITTE, U., RICHLER, C. AND WAHRMAN, J. 1979. Biochemical and cytological differentiation among cichlid fishes of the Sea of Galilee. Evolution, 33, 1-14.

LITTLEJOHN, M. J. 1981. Reproductive isolation: a critical review. In Acehley, W. R. and Woodruff, D. S. (eds.) Evolution and Speciation, Cambridge Univ. Press, pp. 298-344.

MAYNARD SMITH, J. 1966. Sympatric speciation. Am. Natur., 100, 637-650.

MCCONNELL, D. 1935. Changes in the frequencies of the variations of Cepaea nemoralis (Linne). Am. Natur., 69, 614-620.

MURRAY, J. AND ClARKe, B. 1980. The genus Partula on Moorea: speciation in progress. Proc. $R$. Soc., London, B, 211, 83-117.

NEI, M. 1978. Estimation of average heterozygosity and genetic distance from a small number of individuals. Genetics, 89, 583-590.

Nevo, E. 1978. Genetic variation in natural populations: patterns and theory. Theoret. Pop. Biol., 13, 121-177.

OChMAN, H., JONeS, J. S. AND SElAnder, R. K. 1983. Molecular area effects in Cepaea. Proc. natl. Acad. Sci. U.S.A., 80, 4189-4193.

PATTON, J. L., SELANDER, R. K. AND SMITH, M. H. 1972. Genic variation in hybridizing gophers (Thomomys). Syst. Zool., 21, 263-270.

POWELL, J. R. 1975. Protein variation in natural populations of animals. Evol. Biol., 8, 79-119.

RICHARDS, A. V. AND MURRAY, J. 1985. The relation of phenotype to habitat in an introduced colony of Cepaea nemoralis. Heredity, 34, 128-131.

ROSENZWEIG, M. L. 1978. Competitive speciation. Biol. J. Linn. Soc. London, 10, 275-289.

SELANDER, R. K., SMITH, M. H., YANG, S. Y., JOHNSON, W. E. AND GENTRY, J. B. 1971. Biochemical polymorphism and systematics in the genus Peromyscus. I. Variation in the old-field mouse Peromyscus polionotus. Studies in Genetics VI, Univ. Texas Pub., 7103,49-90.

SENE, F. M. AND CARSON, H. L. 1977. Genetic variation in Hawaiian Drosophila. IV. Allozymic similarity between $D$. silvestris and $D$. heteroneura from the island Hawaii. Genetics, 86 , 187-198.

TEMPLETON, A. R. 1981. Mechanisms of speciation-A population genetic approach. Ann. Rev. Ecol. Syst., 12, 23-48.

THORPE, J. P. 1982. The molecular clock hypothesis: biochemical evolution, genetic differentiation and systematics. Ann. Rev. Ecol. Syst., 13, 139-168.

White, M. J. D. 1978. Modes of Speciation. Freeman, San Francisco. 